\title{
ABSTRAK \\ PENGARUH PARTISIPASI POLITIK MASYARAKAT TERHADAP PENINGKATAN PEROLEHAN SUARA MASING-MASING PARTAI POLITIK DI KECAMATAN KEI KECIL TIMUR KABUPATEN MALUKU TENGGARA DALAM PEMILIHAN UMUM TAHUN 2014
}

\author{
Usman A. Matdoan, Dosen STIA Darul Rachman Tual, Maluku \\ 085243478643, E-mail: Upangusman@gmail.com
}

\begin{abstract}
Penelitian ini bertujuan untuk menganalisis tingkat partisipasi politik masyarakat dan pengaruhnya terhadap perolehan suara pada masing-masing partai politik di Kecamatan Kei Kecil Timur Kabupaten Maluku Tenggara. Hasil penelitian menunjukan bahwa tingkat pertisipasi politik yang tinggi memiliki korelasi yang kuat terhadap perolehan suara pada masing-masing partai politik. Rendahnya perolehan suara pada masing-masing partai politik disebabkan karena kurang teredukasinya masyarakat secara politik disebabkan partai-partai politik kurang mensosialisasikan fungsi-fungsi kepartaiinnya.
\end{abstract}

Kata Kunci : Rendahnya edukasi politik masyarakat

Partai politik merupakan sarana atau wadah bagi warga negara untuk ikut serta atau berpartisipasi dalam proses pengelolaan proses bernegara. Dewasa ini partai politik suda sangat akrab di lingkungan kita. Sebagai lembaga politik, partai politik yang dengan sendirinya ada. Kehadiran partai politik mempunyai sejarah yang belum cukup panjang bila dihubungkan dengan kehadiran lembaga-lembaga politik lainnya. Dengan kata lain bisa dikatakan bahwa partai politik merupakan organisasi yang baru dalam kehidupan suatu sistem politik yang dijalankan oleh manusia, jauh lebih muda dibandingkan dengan organisasi negara yang lain. Partai politik, kemunculanya baru ada di negara-negara modern.

Dengan meluasnya hak pilih, dewasa ini, kegiatan politik telah berkembang di luar lembaga-lembaga politik yang formal dengan terbentuknya berbagai kepanitiaan pemelihan yang mengatur proses pengumpulan suara para pendukungnya menjelang masa pemelihan umum. Dalam kaitan ini partai politik dirasa perlu memperoleh dukungan dari berbagai kelompok masyarakat. 
Keikutsertaan masyarakat dalam aktifitas kepartaian ini dalam proses politik disebutkan sebagai proses partisipasi politik. Dimana partisipasi politik dapat dikatakan sebagai kegiatan seseorang atau sekelompok orang untuk ikut serta secara aktif dalam kehidupan politik, antara lain dengan jalan memilih wakil-wakilnya di lembagalembaga perwakilan melalui sistem kepartaian yang secara langsung atau tidak langsung diharapkan dapat mempengaruhi kebijakan pemerintah (publik policy).

Seperti aktifitas politik lainnya, maka proses partisipasi politik meliputi beberapa tindakan atau aktifitas politik yang melibatkan masyarakat antara lain misalnya ; memberikan suara di pemilihan umum (Pemilu), mengahadiri rapat umum, mengadakan hubungan (contecting), atau lobbying dengan pejabat pemerintah atau anggota parlamen, menjadi anggota partai atau pelaku salah satu gerakan sosial. Dari penjelasan di atas dapat difahami bahwa partisipasi politik memiliki berbagai dimensi dan keterkaitannya secara luas dengan aspek-aspek politik yang sesungguhnya menjadikan rakyat sebagai aktor atau pelaku utamanya.

Dalam hubungannya dengan proses partisipasi politik, maka oleh Herbert McClosky, (2005 : 367) menjelaskan bahwa, Partisipasi politik adalah kegiatankegiatan sukarela dari warga masyarakat melalui mana mereka mengambil bagian dalam proses pemilihan penguasa dan secara langsung atau tidak langsung dalam proses pembentukan kebijakan umum ( The term political participation wiil refer to those voluntary activities by which members of a society shore in the selection of rules and, directly or indirectly in the formation of public policy).

Hal terpenting yang menjadi perhatian utama dalam proses partisipasi politik adalah tindakan-tindakan yang bertujuan untuk mempengaruhi proses pengamblan keputusan oleh pemerintah, meskipun fokus utama dari proses patisipasi politik lebih luas dari sekedar mempengruhi keputusan pemerintah, tetapi lebih banyak bersifat abstrak, yakni usaha-usaha untuk mempengaruhi proses alokasi nilai secara otoritatif untuk kepentingan masyarakat.

Dalam konteks politik, terutama dalam konteks demokratisasi, konsep partisipasi politik bertolak dari paham bahwa kedaulatan ada ditangan rakyat, yang dilaksanakan melalui kegiatan bersama untuk menetapkan tujuan-tujuan serta masa depan masyarakat 
itu dan untuk menentukan orang-orang yang akan memegang tampuk kepemimpinan, dengan demikian partisipasi politik merupakan pengejewentahan dari penyelenggaraan kekuasaan politik yang absah oleh rakyat.

Dengan demikian anggota masyarakat yang berpartisipasi dalam proses politik, misalnya melalui pemberian suara atau kegiatan lain, terdorong oleh keyakinan bahwa melalui kegiatan bersama itu kepentingan mereka akan tersalur atau sekurangkurangnya diperhatikan, dan bahwa mereka sedikit banyak dapat mempengaruhi tindakan dari mereka yang berwewenang untuk membuat keputusan yang sifatnya mengikat, atau dengan kata lain, mereka percaya bahwa kegiatan partisipasi yang mereka terlibat di dalamnya mempunyai efek politik.

Melalui penjelasan di atas, dapat dipahami bahwa partisipasi politik erat sekali kaitannya dengan kesadaran politik masyarakat. Karena semakin sadar bahwa dirinya diperintah, orang kemudian menuntut diberikan hak bersuara dalam penyelenggaraan pemerintahan, kesedaran ini muncul sebagai akibat semakin menguatnya pemahaman masyarakat terhadap proses politik, sebaliknya partisipasi politik masyarakat yang rendah pada dasarnya dianggap sebagai suatu fenomena politik yang tidak terlalu baik, kerana dapat ditafsirkan banyak warga masyarakat yang tidak menaruh perhatian terhadap masalah-masalah politik.

Namun demikian ada pula anggota masyarakat yang berpendapat bahwa partisipasi politik hanya mencakup kegiatan-kegiatan yang bersifat positif. Menurut Huntington dan Nelson, bahwa partisipasi politik adalah aktifitas yang ada unsur deskruktif yang menyebabkan meningkatnya eskalasi dan mobilisasi masyakat untuk tindakan-tindakan yang sifatnya dapat mengganggu stabilitas. Namun demikian melihat begitu pentingnya partisipasi politik masyarakat sebagai wujud keterlibatan masyarakat dalam proses demokratisasi bangsa, ada warga negara yang sama sekali tidak melibatkan diri dalam proses partisipasi politik yang merupakan anti-thesis terhadap proses partisipasi politik masyarakat, muncul kemudian pertanyaan kenapa ada orang yang apatis terhadap proses partisipasi politik, jawaban sementara yang bisa dikemukakan dalam menjawab pertanyaan ini adalah, mereka tidak terlibat atau tidak 
berpatisipasi karena munculnya sikap acuh tak acuh dan tidak tertarik pada proses politik tertentu atau kurang paham mengenai masalah politik.

Ada juga berkeyakinan bahwa usaha untuk mempengaruhi pemerintah tidak akan berhasil, dan ada yang secara sengaja untuk tidak menyalurkan hak-hak politiknya, numun sebaliknya ada kemungkinan bahwa orang tidak berpartisipasi dalam proses politik, karena berpendapat bahwa keadaan politik tidak terlalu buruk dan siapa yang akan dipilih tidak akan mampu mengubah keadaan yang ada, dengan demikian mereka tidak perlu memanfaatkan hak-hak politiknya. Jadi "apatis" dalam pandangan ini tidak merujuk pada rasa kecewa atau frustasi, tetapi malahan sebagai manisfestasi dan rasa puas terhadap sistem politik yang ada.

Melalui kajian di atas, maka dapat dipahami secara konseptual bahwa antara partisipasi politik masyarakat dengan eksistensi partai politik memiliki hubungan atau korelasi yang sangat positif, dimana semakin kuat tingkat partisipasi politik terhadap partai politik tertentu akan berdampak positif terhadap eksistensi suatu partai politik atau sebaliknya semakin rendanya tingkat partisipasi politik masyarakat terhadap partai politik tertertu akan berpengaruh negetif terhadap eksistensi sistem kepartaian tertentu.

\section{METODE PENELITIAN}

Penelitian ini merupakan suatu model penelitian dengan menggunakan desain kunatitatif diskriptif dengan menggunakan rumus korelasi Statistik Product Moment untuk mengetahui hubungan antara kedua variabel dalam penelitian ini, yakni partisipasi politik masyarakat sebagai variabel bebas (variabel x) dan tingkat perolehan suara masing-masing partai politik sebagai variabel terikat (variabel y) adapun rumus kerolasi Statistik Product Moment adalah sebagai berikut:

$$
\Gamma x y=\frac{n \sum X Y-\left(\sum X\right)\left(\sum Y\right)}{\sqrt{\left[n \sum X^{2}-\left(\sum X\right)^{2}\right]\left[n \sum Y^{2}-\left(\sum Y\right)^{2}\right]}}
$$

Keterangan :

$\mathrm{r} \quad$ : koofesiensi korelasi product moment

$\mathrm{x}$ : skor variabel bebas 
y : skor variabel terikat

$\mathrm{xy}$ : hasil penjumlahan variabel $\mathrm{xy}$

$\mathrm{n}$ : jumlah sampel

Uji $t$ untuk melihat tingkat signifikansi diantara kedua variabel di atas dengan rumus sebagai berikut :

$$
\mathrm{t}=\frac{\mathrm{r}^{2} \sqrt{ } \mathrm{n}-2}{\sqrt{1-\mathrm{r}^{2}}}
$$

\section{PEMBAHASAN}

Samuel P. Huntington dan Joan M. Nelson dalam Meriam Budihardjo Edisi Revisi (2010 : 368), mendefenisikan partisipasi politik “By political participation we mean activity by privat citizens designed to influence government decision making. Participation may be invidual or kolective organized or spontaneous, sustained or spor adic, peaceful or violent, legal or illegal, effective or ineffective”, artinya; partisipasi politik adalah kegiatan warga yang bertindak sebagai pribadi-pribadi, yang dimaksud untuk mempengaruhi pembuatan keputusan oleh pemerintah. Partisipasi bisa bersifat individual atau kolektif, terorganisir atau spontan, mantap atau sporadis, secara damai atau dengan kekerasan, legal atau illegal, efektif atau tidak efektif.

Samuel P. Huntington, kembali menambahkan bahwa di Negara-negara demokrasi konsep partisipasi politik bertolak dari paham bahwa kegiatan politik ada ditangan rakyat, yang dilaksanakan melalui kegiatan bersama untuk menentukan tujuantujuan serta masa depan masyarakat itu dan untuk menentukan orang-orang yang akan memegang tampuk pimpinan. Jadi partisipasi politik merupakan pengejewentahan kekuasaan politik yang absah oleh rakyat.

Namun demikian ada pandangan yang berbeda terkait dengan konsep partsipasi politik, misalnya ada kecenderungan pendapat sebagian sarjana bahwa yang dinamakan partisipasi politik hanya terbatas pada kegiatan yang sifatnya sukarela saja, yaitu kegiatan yang dilakukan tanpa paksaaan dari siapapun, pemikiran ini dikemukakan oleh ilmuan politik seperti, Gabrial Almond dan Kawan-kawan (1997 : 286).

Akan tetapi perlu difahami bahwa dalam hampir setiap kegiatan partisipasi politik selalu terdapat unsur tekanan atau manipulasi, tetapi di Negara-negara demokrasi 
yang telah mapan, tekanan-tekanan dalam proses partisipasi politik jauh lebih sedikit bila dibanding dengan Negara-negara otoriter atau Negara berkembang. Disamping itu di Negara-negara berkembang pada umunya terdapat kombinasi dari unsur sukarela dan unsur manipulasi dengan berbagai bobot dan takaran, Meriam Budihadjo (Edisi Revisi, $2010: 370)$.

\section{Partisipasi Politik di Negara Demokrasi.}

Secara umum kegiatan yang dapat dikatagorikan sebagai partispasi politik menunjukan berbagai bentuk dan intensitas. Terdapat pembedaan jenis partisipasi menurut jenis dan intensitasnya. Orang yang tidak mengikuti kegiatan secara tidak intesif yaitu kegiatan yang tidak banyak menyita waktu dan yang biasanya tidak berdasarkan prakarsa sendiri misalnya (memberikan suara pada pemilihan umum) atau golput, dalam hal ini jumlah keterlibatan masyarakat dalam konteks apatis politik sangat tinggi. Atau sebaliknya kecil sekali jumlah orang yang secra aktif dan sepenuh waktu melibatkan diri dalam proses politik, atau menjadi aktivis atau aktor politik.

\section{Sejarah Perkembangan Partai Politik.}

Apabila ditelaah dari segi sejarah perkembangannya, maka partai politik pertama-tama lahir di Negara-negara Eropa Barat, dengan meluasnya gagasan bahwa rakyat merupakan faktor yang perlu diperhitungkan serta diikutsertakan dalam proses politik, maka partai politik telah lahir secara spontan dan berkembang menjadi penghubung antara rakyat di satu pihak dan pemerintah di pihak lain. Pada awal perkembangannya, yakni pada akhir dekade 1800-an di Negara-negara barat seperti Inggris dan Perancis, kegiatan politik dipusatkan pada kelompok-kelompok politik dalam parlemen. Kegiatan ini mula-mula bersifat elitis dan aristokratis, yang sifatnya mempertahankan kepentingan kaum bangsawan terhadap tuntutan-tuntutan raja.

Namun dengan meluasnya hak pilih, kegiatan politik juga berkembang di luar parlemen dengan terbentuknya panitia-panitia pemilihan yang mengatur pengumpulan suara para pendukungnya menjelang masa pemilihan umum (kadang-kadang dinamakan caucus party). Oleh karena dirasa perlu memperoleh dukungan dari berbagai golongan, kelompok-kelompok politik di parlamen lambat laun juga berusaha mengembangkan organisasi masa maka pada akhir abad ke 19 lahirlah partai politik yang pada masa 
selanjutnya berkembang menjadi penghubung (link) antara rakyat di satu pihak dan pemerintah di pihak lain.

\section{Fungsi Partai Politik.}

Ada pandangan yang berbeda secara mendasar mengenai partai politik di Negara yang demokratis dan di Negara oteriter, perbedaan pandangan tersebut berimplikasi pada pelaksanaan tugas dan fungsi partai di masing-masing Negara. Di Negara demokratis partai relatif dapat menjalankan fungsi sesuai dengan harkatnya pada saat kelahirannya, yakni menjadi wahana bagi warga Negara untuk berpartisipasi dalam pengelolaan kehidupan bernegara dan memperjuangkan kepentingannya dihadapan penguasa, sebaliknya di Negara oteriter, partai politik tidak dapat menunjukan fungsinya. Tetapi lebih banyak menjalankan kehendek penguasa (Miriam Budiharja, Edisi Revisi, 2010 : 405). Lebih lanjut, Miriam Budiharja (2010 : 405 ) menjelaskan secara berturut-turut fungsi partai politik, antara lain sebagai berikut :

\section{Partai Politik Sebagai Sarana Komunikasi Politik}

Oleh Sigmun Neumann (2005 : 256), bahwa dalam hubungannya dengan komunikasi politik, kehadiran partai politik merupakan perantara yang besar yang menghubungkan kekuatan-kekuatan dan idiologi sosial dan lembaga pemerintah yang resmi dan mengaitkannya dengan aksi politik di dalam masyarakat yang lebih luas. Akan tetapi sering terdapat gejala bahwa pelaksanaan fungsi komunikasi ini, sengaja atau tidak sengaja, menghasilkan informasi yang berat sebelah dalam menimbulkan kegelisahan dan keresahan dalam masyarakat, mis-informasi semacam itu menghambat perkembangan politik yang sehat.

\section{Partai Politik Sebagai Sarana Sosialisasi Politik.}

Dalam ilmu politik, sosialisasi politik diartikan sebagai suatu proses yang melaluinya seseorang memperoleh sikap dan oreantasi terhadap fenomena politik, yang umumnya berlaku dalam masyarakat di mana ia berada. Ia adalah bagian dari proses yang menentukan sikap politik seseorang, misalnya mengenai nasionalisme, kelas sosial, suku bangsa, idiologi, hak dan kewajiban.

Dimensi lain dari sosialisasi politik adalah proses yang melaluinya masyarakat menyampaikan "budaya politik" yang norma-norma dan nilai-nilai, dari satu lenerasi 
ke generasi berikutnya selalu terjaga, dengan demikian sosialisasi politik merupakan faktor terpenting dalam terbentuknya budaya politik (political culture) suatu bangsa.

Demikian juga, menurut ahli sosiologi politik seperti M. Rush (1992 : 27) bahwa: Sosialisasi politik adalah proses yang melaluinya orang dalam masyarakat tertentu belajar mengenali sistem politiknya. Proses ini sedikit banyak menentukan persepsi dan reaksi mereka terhadap fenomena politik. Selain itu, sisi lain dari fungsi sosialisasi partai politik, adalah upaya menciptakan citra (image) bahwa partai politik memperjuangkan kepentingan umum. Hal ini penting jika dikaitkan dengan tujuan partai untuk menguasai pemerintahan melalui kemenaganan dalam pemilihan umum, karena itu partai politik harus memperoleh dukungan sebanyak mungkin, dan partai politik berkepentingan agar pendukungnya mempunyai solidaritas yang kuat dengan partainya.

Dalam perspektif yang berbeda hal yang lebih tinggi nilainya, apabila partai politik menjalankan fungsi sosialisasi yang lain misalnya, mendidik anggota anggotanya menjadi manusia yang sadar akan tanggung jawab sebagai warga Negara dan menempatkan kepentingan sendiri dibawah kepentingan nasional. Namun demikian, tidak dapat disangkal bahwa partai politik lebih banyak mengutamakan kepentingan partai di atas kepentingan nasional, loyalitas yang diajarkan adalah loyalitas kepada partai yang melebihi loyalitas kepada Negara, dengan demikian partai politik mendidik kadernya untuk melihat dirinya dalam konteks yang sangat sempit. Pandangan ini malahan dapat mengakibatkan pengkotakan dan tidak membantu proses integrasi, yang bagi Negara-negara berkembang menjadi begitu penting.

Dari pendekatan yang berbeda proses sosialisasi politik berjalan seumur hidup, terurama pada masa kanak-kanak, proses ini berkembang melalui keluarga, sekolah, peer group, tempat kerja, pengalaman sebagai orang dewasa dan partai politik dimana ia menjadi penghubung yang mensosialisasikan nilai-nilai politik generasi yang satu ke generasi berikutnya. Di sinilah letaknya partai politik dalam memainkan peran sebagai sarana sosialisasi politik. Pelaksanaan fungsi sosialisasinya dilakukan melalui berbagai cara yaitu media mssa, ceramah-ceramah, penerangan, kursus kader dan sebagainya (Sigmund Neuman,1992: 352) 


\section{Partai Politik Sebagai Sarana Rekrutmen Politik}

Fungsi rekrutmen politik berkaitan erat dengan masalah seleksi kepemimpinan, baik kepemimpinan internal maupun kepemimpinan nasional yang lebih luas, kepentingan internalnya, setiap partai membutuhkan kader-kader yang berkualitas, karena hanya dengan kader yang demikian ia dapat menjadi partai yang mempunyai kesempatan untuk mengembangkan diri. Dengan mempunyai kader-kader yang baik, partai politik tidak akan sulit menentukan pemimpinnya sendiri dan mempunyai peluang untuk mengajukan calonnya ke bursa kepemimpinan nasional (Arend Liphart, 1995 : 409).

Selain untuk tingkatan seperti itu, partai politik juga berkepentingan memperluas atau memperbanyak keanggotaan. Maka partai politik pun berusaha menarik sebanyak mungkin orang untuk menjadi anggotanya. Dengan didirikannya organisasi-organisasi buruh, petani, pemuda, mahasiswa, organisasi wanita dan sebagainya atau dengan kata lain kesempatan untuk berpartisipasi diperluas. Rekrutmen politik menjamin kontinuitas dan kelestarian partai, sekaligus merupakan satu cara untuk menjaring dan melatih calon-calon pimpinan. Ada berbagai cara untuk melakukan rekrutmen politik, yaitu kontak pribadi, persuasi atau cara-cara lain.

\section{Partai Politik Sebagai Sarana Pengatur Konflik}

Potensi konflik selalu ada di setiap masyarakat, apalagi di masyarakat yang bersifat hetoregen, apakah dari segi etnis (suku bangsa), soaial ekonomi ataupun agama. Setiap perbedaan tersebut menyimpan potensi konflik. Apabila keanekaragaman itu terjadi di Negara yang menganut paham demokrasi, persaingan dan perbedaan pendapat dianggap hal yang wajar dan mendapat tempat, akan tetapi di dalam Negara yang hetoregen sifatnya, potensi pertantangan lebih besar dan dengan muda mengundang konflik (Meriam Budiardjo, 2010 : 409).

Sejalan dengan itu, misalnya oleh Arend Lijphart (1998) bahwa, perbedaanperbedaan atau perpecahan ditingkat masa bawah dapat diatasi oleh kerja sama antara elit-elit politik, dalam konteks kepartaian, para pemimpin partai adalah elit politik. Secara ringkas dapat dikatakan bahwa partai politik dapat menjadi penghubung spikologi dan organisasional antara warga Negara dengan pemerintahnya. Selain itu 
partai politik juga melakukan konsolidasi dan artikulasi serta tuntutan-tuntutan yang beragam sifatnya yang berkembang diberbagai kelompok masyarakat. Partai politik juga merekrut orang-orang untuk diikutsertakan dalam konteks pemilihan wakil-wakil rakyat dan menemukan orang-orang yang cakap untuk menduduki posisi-posisi eksekutif. Pelaksanaan fungsi-fungsi ini dapat dijadikan instrument untuk mengukur keberhasilan atau kegagalan partai politik terutama di Negara demokrasi. Dipihak lain dapat dilihat bahwa seringkali partai politik malahan mempertajam pertantangan yang ada. Dan jika hal ini dalam suatu masyarakat kadar konsensus nasionalnya, peran semacam ini dapat membahayakan stabilitas politik.

\section{Kalasifikasi Sistem Kepartaian.}

Pada bagian pendahuluan di atas, terdapat beberapa sarjana beranggapan bahwa diperlukan suatu analisis tertentu dengan meneliti perilaku perilaku-perilaku partai politik sebagai bagian yang tidak terpisahkan dari suatu sistem, yaitu bagaimana partai politik berinteraksi dengan unsur-unsur lain dari sistem itu. Analisis semacam ini yang dinamakan "sistem kepartaian" (party systems) konsep ini untuk pertama kali dikembangkan oleh Maurice Duverger (1998 :352) dalam bukunya Political Parties. Menurutnya partai politik diklasifikasi menurut tiga kategori, yaitu sistem partai tunggal, sistem dwi partai dan sistem multi partai yang dijelaskan sebagai berikut :

\section{Sistem Partai Tunggal}

Ada sebagian ahli perpandangan bahw istilah sistem partai tunggal merupakan istilah yang menyangkal diri sendiri (contradiction in terminis) sebab suatu sistem selalu mengandung lebih dari satu bagian (pars). Namun demikian, istilah ini telah tersebar luas di kalangan masyarakat dan dipakai baik untuk partai yang benar-benar merupakan satu-satunya partai dalam suatu Negara maupun untuk partai yang mempunyai kedudukan dominan di antara beberapa partai lain.

Sistem kepartaian, terutama di Negara-negara yang baru lepas dari kolonialisme ada kecenderungan kuat untuk menggunakan pola sistem partai tunggal karena pemimpin sering dihadapkan dengan masalah bagaimana mengintegrasikan berbagai golongan, daerah serta suku bangsa yang berbeda corak sosial serta pandangan hidupnya. 
Dalam konteks ini dikhawatirkan bahwa keanekaragaman sosial dan budaya ini tidak diatur dengan baik akan terjadi gejolak sosial politk yang menghambat usaha pembangunan. Padahal pembangunan itu harus memfokuskan diri pada suatu, program ekonomi yang berorentasi masa depan (future oriented). Dalam serajah kepartaian di Indonesia, sejak kemerdekaaan tahun 1945 ada usaha mendirikan partai tunggal sesuai dengan pemikiran yang pada saat itu terutama ssistem kepartaaian yang dianut oleh Negara-negara yang baru melepaskan diri dari rezim kolonial. Pada aspek ini partai politik diharapkan akan menjadior motor perjuangan. Akan tetapi dalam beberapa perjalanan kemudian usaha pembentukan partai tunggal itu dihentikan sebelum terbentuknya secara konkret, penolakan disebabkan karena dianggap berbau fasis.

\section{Sistem Dwi Partai.}

Peter G.J. Pulzer (1998 : 139), menjelaskan bahwa dalam kepustakaan ilmu politik, pengertian sistem dwi partai biasnya diartikan bahwa ada dua partai di antara beberapa partai, yang berhasil memenangkan dua tempat teratas dalam pemilihan umum secara bergiliran, dan dengan demikian, sistem dwi partai dianggap mempunyai kedudukan dominan dalam suatu sistem politik. Dewasa ini hanya ada beberapa Negara yang memiliki ciri-ciri sistem dwi partai, antara lain misalnya Inggris, Amerika Serikat, Filipina, Kanada dan Salandia Baru.

Lebih lanjut Peter G.J. Pulzer, menambahkan bahwa dalam sistem ini partaipartai dengan jelas dibagi dalam partai yang berkuasa dan partai oposisi, dengan demikian jelaslah bahwa dimana letak partai yang kalah berperan sebagai oposisi yang setia (loyal opposition) terhadap kebijakan partai yang duduk dalam pemerintahan, dengan pengertian bahwa peran ini dapat bertukar tangan. Dalam persaingan memenangkan pemilihan umum kedua partai berusaha untuk merebut dukungan orangorang yang ada ditengah dan disering dinamai pemilih mengambang (floating vote) atau pemilih ditengah (median vote).

Sistem dwi partai juga disebut sebagai a convenient system for contented people dan dalam kenyataannya adalah bahwa sistem dwi partai dapat berjalan dengan baik apabila terpenuhi tiga syarat, yaitu ; komposisi masyarakat bersifat homogen (social homogeneity), adanya konsensus yang kuat dalam masyarakat mengenai asas dan tujuan 
sosial dan politik (political consensus), dan adanya kontinuitas sejarah (historical continuity), Peter G.J. P. Pulzer, (1998 : 147). Pada umumnya dianggap bahwa sistem dwi partai lebih kondusif untuk terpeliharanya stabilitas karena ada perbedaan yang jelas antara partai pemerintah dan partai opsisi, namum demikian menurut ilmuan politik Robert Dahl (1996 : 394), bahwa dalam masyarakat yang terpolarisasi sistem dwi partai malahan dapat mempertajam perbedaan pandangan antara kedua belah pihak, karena tidak ada kelompok di tengah-tengah yang dapat meredahkan suasana konflik.

Sistem dwi partai umumnya diperkuat dengan digunakannya sistem pemilihan single member constituency (sistem distrik) dimana dalam setiap daerah pemilihan hanya dapat dipilih satu wakil saja. Sistem pemilihan ini cenderung menghambat pertumbuhan partai kecil, sehingga dengan demikian memperkokoh sistem dwi partai, (Rebert A. Dahl, 1996 : 403). Dalam konteks Indonesia, sejak tahun 1960 an ada usaha mengganti sistem multi partai yang telah berjalan sejak lama dengan sistem dwi partai, agar sistem ini dapat membatasi pengaruh partai-partai yang telah lama mendominasi kehidupan politik. Beberapa ekses dirasakan menghalangi badan eksekutuf untuk menyelenggarakan pemerintahan yang lebih baik. Akan tetapi eksperimen dwi partai ini, sesudah diperkenalkan di beberapa wilayah, ternyata mendapat pertantangan dari partai-partai yang merasa terancam eksistensinya, sehingga gerakan ini dihentikan sejak tahun 1969, (Arbi Sanit, $2002: 25$ ).

\section{Sistem Multi Partai.}

Menurut Meriam Budihardjo, (2010 : 418) pada umumnya dianggap bahwa keanekaragaman budaya politik suatu masyarakat mendorong kearah sistem multi partai, perbedaan tajam antara ras, agama, atau suku bangsa mendorong golongangolongan masyarakat lebih cenderung menyalurkan ikatan-ikatan terbatasnya (primordial) dalam satu wadah yang sempit saja. Lanjut Meriam, bahwa pola multi partai lebih sesusai dengan pruralitas budaya dan politik dari pada pola dwi partai. Sebaran sistem multi partai misalnya dapat ditemukan antara lain di Indonesia, Malaysia, Nederland, Austeralis, Prancis, Swedia dan Federasi Rusia. Prancis misalnya, mempunyai partai politik yang berkisar antara 17 dan 18, sedangkan federasi Rusia sesudah jatuhnya partai komonis, jumlah partai mencapai 43 . 
Sistem multi partai, apabila jika dihubungkan dengan sistem pemerintahan parlementar misalnya ada kecenderungan untuk menitik beratkan kekuasaan pada badan legisletif, sehingga peran badan eksekutif sering melemah dan ragu-ragu. Hal ini sering disebabkan karena tidak ada satu partai yang cukup dominan untuk membentuk suatu pemerintahan sendiri, sehinga ada semacam keterpaksaan dalam membentuk koalisi dengan partai-partai lain. Dalam keadaan semacam ini partai yang berkoalisi harus selalu musyawarah kompromi dengan mitranya dan menghadapi kemungkinan bahwa sewaktu-waktu dukungan dari partai yang duduk dalam koalisi akan ditarik kembali, sehingga mayoritasnya dalam parlemen hilang.

\section{KESIMPULAN}

1. Bahwa hubungan antara kedua varibel penelitian ini menunjukan hubungan yang signifikan

2. Hubungan ini menunjukan bahwa apabila tingkat partisipasi politik masyarakat yang tinggi akan berdampak positif terhadap perolehan suara pada masing-masing partai politik di Kecamatan Kei Kecil Timur Kabupaten Maluku Tenggara.

3. Bahwa rendahnya tingakat perolehan suara pada masing-masing partai politik di Kecamatan Kei Kecil Timur Kabupaten Maluku Tenggara, menunjukan bahwa masing-masing partai politik belum memaksimalkan fungsi kepartaian sehingga masing-masing partai politik tidak memperoleh suara yang signifikan sebagai mana target politik sebelumnya.

\section{DAFTAR PUSTAKA}

Anwar M dan Syafii. 2008. Menggapai Kedaulatan Rakyat. Mizan. Bandung

Arbi Sanit. 2002. Sistem Politik Indonesia. Gramedia. Jakarta

Arend Liphart. 1995. Sejarah Perkembangan Partai Politik di Indonesia. Dian Rakyat. Jakarta

Duverger. 2003. Maurice Political Partis. London Methuen and Co, Ltd. London

Gabrial Almond dan Kawan-kawan. 1997. Comporative Politics A. Develompmental Approach. Little Bron and Co. Boston

Herbert McClosky. 2005. Menuju ke Parlemen Sempurna. Gaja Mada Press. Yogyakarta

Jean Blondel .2006. Kabinet Government Cambridge, Edisi Terjemahan. UI Press. Jakarta 
Meriam Budihardjo. 2010. Dasar-Dasar Ilmu Politik. Gramedia Pustaka. Jakarta

McClosky. 2005. Political Partisipation, Internasional Encylopedia, Edisi Terjemahan. UI Press. Jakarta

M. Rush .1992. Membangun Politik di Indonesia, Beberapa Masalah Organisasi Politik. Makalah pada Seminar dan Kongres Nasional 1 Asosiasi Ilmu Politik, Universitas Indonesis Jakarta.

Peter G.J. P. Pulzer. 1998. Golkar of Indonesia, An Alternative to the Partty Sistem. Gramedia Press. Jakarta

Sri Sumantri. 1998. Sistem Dua Partai. Binatjipta. Bandung 